\title{
Mercury exposure and malaria prevalence among gold miners in Pará, Brazil
}

\author{
Exposição a mercúrio e prevalência de malária entre \\ garimpeiros de ouro do Pará, Brasil
}

Ellen K. Silbergeld ${ }^{1}$, Denis Nash ${ }^{2 *}$, Circey Trevant ${ }^{1}$, G. Thomas Strickland ${ }^{2}$, Jose Maria de Souza ${ }^{3}$ and Rui S.U. da Silva ${ }^{3}$

\begin{abstract}
Economic development, including resource extraction, can cause toxic exposures that interact with endemic infectious diseases. Mercury is an immunotoxic metal used in the amalgamation of gold, resulting in both occupational exposures and environmental pollution. A cross-sectional medical survey was conducted in 1997 on 135 garimpeiros in Para, Brazil, because of their risks of both mercury exposure and malaria transmission. Mean levels of blood and urine mercury were well above non-exposed background levels. Twentysix subjects had malaria parasitemia: Health symptoms consistent with mercury exposure were reported, but neither symptoms nor signs correlated with mercury levels in blood or urine. We did not find a dose response relationship between mercury exposure and likelihood of prevalent malaria infection, but there was a possible reduction in acquisition of immunity that may be associated with conditions in gold mining, including mercury exposure.
\end{abstract}

Key-words: Mercury. Garimpagem. Malaria. Toxicity.

Resumo O desenvolvimento econômico, incluindo extração de recursos naturais, pode causar exposições tóxicas que interagem com doenças infecciosas endêmicas. O mercúrio é um metal imunotóxico usado na amalgamação do ouro, resultando em exposição ocupacional e poluição ambiental. Devido aos riscos da exposição ao mercúrio e transmissão de malária em 135 garimpeiros do Pará, Brasil, uma avaliação médica "crosssectional" foi coduzida em 1997. Níveis médios de mercúrio no sangue e na urina encontram-se bem acima dos níveis basais daqueles não expostos. Vinte e seis indivíduos apresentaram parasitemia de malária; sintomas relacionados com exposição ao mercúrio foram adquiridos, mas nenhum dos sintomas/sinais está correlacionado com níveis de mercúrio no sangue ou na urina. Não foi encontrada nenhuma relação de dose-resposta entre exposição ao mercúrio e provável infecção de malária prevalente. Entretanto, verificou-se uma possível redução na aquisição de imunidade que talvez esteja relacionada às condições de garimpagem, incluindo exposição ao mercúrio.

Palavras-chaves: Mercúrio. Garimpagem. Malária. Toxicidade.

During processes of development and resource extraction, populations in many developing countries are increasingly being exposed to chemical pollutants, while exposure to endemic infectious diseases continues. Thus, uncontrolled development may add to their disease burden by altering host exposures and/or susceptibility to infection. The impacts of global and local environmental change on infectious disease has been understood mainly in terms of population density and the distribution of pathogens and their vectors ${ }^{12434}$. For example, temporal increases in malaria incidence in Rwanda ${ }^{22}$ and Colombia ${ }^{4}$ have been associated with the effects of periodic El Niño events and overall surface warming on vector thermosensitivity. No studies have been conducted on the interaction of chemical pollutants and the epidemiology of infectious disease.

\footnotetext{
1. Department of Environmental Health Sciences, Johns Hopkins University, Bloomberg School of Public Health, Baltimore MD, USA. 2. Department of Epidemiology and Preventive Medicine, University of Maryland School of Medicine, Baltimore, MD, USA. 3. Instituto Evandro Chagas, Fundação Nacional de Saúde, Ministério da Saúde, Belém, Pará, Brazil.

"Current affiliation: New York City Department of Health, New York NY, USA

Supported by grants from the Pan American Health Organization, the W. Alton Jones Foundation, and the Heinz Family Foundation.

Address to: Ellen K. Silbergeld, Ph.D. Department of Environmental Health Sciences, Johns Hopkins University Bloomberg School of Public Health, 615 N. Wolfe Street, 21205, Baltimore, MD

Tel: (410)955-8678; fax; (410)955-9334

e-mail: esilberg@jhsph.edu

Recebido para publicação em 26/3/2001.
} 
Malaria has long been recognized by health officials in Brazil to be associated with gold mining activity, and control of malaria in mining regions is a high priority in Brazil $^{10}$. In the States of Pará and Rondônia, where extensive gold mining activities are occurring, the prevalence of malaria and API rates are the highest in the country ${ }^{25}$. In 1994, these two states accounted for over half of all reported cases of malaria in Brasil ${ }^{25}$. Artisanal mining of alluvial gold creates ecologic changes (deforestation, destruction of aquatic systems, creation of pools in place of free flowing streams and rivers) that increase breeding niches for the Anopheles mosquito vectors of malaria. Mining also increases the size of dispersed settlements ${ }^{8}$ often of individuals from other parts of Brazil (where malaria is largely absent) to Amazônia, which results in exposure of immunologically naive persons to infection.

Gold mining within the Brazilian Amazon is conducted by some large scale operations but mostly by small scale miners, or garimpeiros, who extract gold from dredged river bed and bank sediments. Elemental mercury is used in an open process. First, the gold in sediments is amalgamated crudely by hand mixing of liquid elemental mercury with sediments forming a goldmercury amalgam. Second, the amalgam is burned to remove the mercury. This refining process is usually begun at the garimpo, using propane heat sources, and then finished in "casas de ouro" in small towns were gold is bought and sold". In both amalgamation and burning, the garimpeiros experience significant dermal and inhalation exposures to mercury ${ }^{15}$. Substantial amounts of mercury are released into the environment from amalgamation and also in some regions from soil erosion ${ }^{17} 33$. Increased mercury levels in fish and sediments in downstream ecosystems have been documented ${ }^{19} 2021$. Exact figures on gold production and mercury use are unavailable since much of this activity is illegal and unreported. It is estimated by CETEM (Brazilian Council on Mining Technology) that about 14 metric tons of gold are mined in this fashion each year in the state of Pará (Villas Boas, 1999 personal communication). For every kilogram of gold mined by the garimpeiros through uncontrolled processes, at least one kilogram of mercury is released into the environment ${ }^{17}$. Despite attempts to introduce appropriate technology, few attempts at mercury recovery are made at any stage in the process.

This situation has stimulated us to investigate possible interactions between toxic chemical exposures and infectious diseases. Mercury is a well characterized immunotoxic metal and it is reported to impair host responses to viral infections in animal models ${ }^{13}{ }^{18}$. We have recently reported that mercury exposure of BALB/ c mice impairs resistance to infection and blocks immunity to the murine plasmodium, Plasmodium yoelii ${ }^{27}$. and Bagenstose et $\mathrm{al}^{2}$ reported that mercury can also interact with leishmaniasis in mice.

The objectives of this study are to describe the extent of exposures to mercury and malaria in a group of miners (garimpeiros) and their helpers at a single gold mining site (garimpo) in the Tapajós River area in the State of Pará, Brazil, and to evaluate any evidence for interactions between mercury exposure and malaria infection. The specific hypothesis of interest is whether or not there is a positive association between mercury exposure, as determined by blood and urinary mercury levels, and malaria prevalence, as determined by parasitemia. The site selected for this initial investigation is a gold mining site in the Brazilian Amazon, where the miners are exposed both to mercury in amalgamation and crude refining, and to the local Anopheles vector of malaria.

\section{MATERIALS AND METHODS}

In 1997, a team of two physicians trained in tropical medicine (GTS and RSUS), four medical technicians, and a project co-coordinator flew to an airstrip at the Piranha garimpo in the State of Pará. This site is located in an inaccessible region of the Tapajós watershed approximately $200 \mathrm{~km}$ south of Itaituba. Chosen for its use of mercury in the mining process as well as being an area of malaria endemicity (Jair, FNS-Itaituba, personal communication), the Piranha site is active year round and has been in operation since 1962. Selection of and access to the site was arranged in cooperation with the Associations of Mine Owners and Mine Workers of the Tapajós. Over a six day period, a total of 135 people working in the garimpo gave informed consent and agreed to participate in a cross sectional survey. This represented almost the entire garimpo population and included everyone except those from the most isolated sites or those who for other reasons could not get to the airstrip/trading post where the interviews and exams were conducted.
A medical history and physical exam were performed. Two 15-ml whole blood samples and a 20-ml urine specimen were collected from each subject for laboratory tests. Methods for blood collection are the same as used by Grandjean et al (1999) ${ }^{12}$. The urine samples were prepared for mercury analysis in Rio de Janeiro and Santarém, Brazil. Blood and urinary mercury levels were measured by Atomic Absorption Spectroscopy in the laboratory of Dr. O. Malm, Universidade Federal do RJ, which participates in an international QA/QC program. Malaria infection was assessed by a Giemsa-stained thin blood film obtained from a finger prick. The slides were examined microscopically at the garimpo by a technician from the Itaituba office of the Fundação Nacional de Saúde (FUNASA) and then reexamined by a technician at the Evandro Chagas Institute in Belém (blinded to the initial assessment). A detailed questionnaire in Portuguese ascertained self-reported history of malaria and other infections, health history, and details of mercury use/ 
exposure, as well as demographic and lifestyle characteristics.

All statistical analyses were performed using SAS JMP software for Macintosh. ANOVA was used to assess statistical significance for continuous variables and a chi square test was used for categorical variables. The study protocol was approved by the Institutional Review Boards at the University of Maryland Medical School, and by the Evandro Chagas Institute - FUNASA.

\section{RESULTS}

All subjects who came to the study site agreed to participate in the study. The majority of the participants were male (Table 1). The mean age was 33.1 and ranged from 2 to 58 years. Almost $90 \%$ had not completed primary level education. Over $70 \%$ were smokers and a

Table 1 - Selected demographic characteristics of a gold mining population from Pará, Brasil.

\begin{tabular}{lrr}
\hline & $\mathrm{N}$ & $\%$ \\
\hline Gender & 104 & 77.0 \\
$\quad$ male & 31 & 23.0 \\
$\quad$ female & 33.1 & 9.6 \\
Age, mean (SD) & & \\
Education level, & 28 & 20.7 \\
$\quad$ literate & 92 & 68.1 \\
$\quad$ primary grade incomplete & 8 & 5.9 \\
primary grade complete & 7 & 5.2 \\
$\quad$ > primary grade complete & & \\
Smoking & 84 & 72.7 \\
$\quad$ current smoker & 8.4 & 9.0 \\
$\quad$ pack years, mean (SD) & 93 & 72.7 \\
Current alcohol use & & \\
Fish consumption & 29 & 21.5 \\
$\quad$ < once per week & 59 & 43.7 \\
once per week & 40 & 29.6 \\
2-3 times per week & 7 & 5.2 \\
> 3 times per week &
\end{tabular}

similar percentage reported alcohol use. Almost $80 \%$ consumed fish, a potential dietary source of mercury in this region ${ }^{20}$. at least once per week. More than half of the subjects reported prior episodes of malaria infection (Table 2 ); while $18 \%$ reported having a prior episode of

Table 2 - Self-reported data on malaria, leishmaniasis, and tuberculosis among gold miners from Pará, Brasil.

\begin{tabular}{lrr}
\hline Number of past malaria infections & N & $\%$ \\
\hline Never & 5 & 3.8 \\
$1 \mathrm{x}$ & 23 & 17.3 \\
$2 \mathrm{x}$ & 16 & 12.0 \\
$3 \mathrm{x}$ & 10 & 7.5 \\
$4 \mathrm{x}$ & 11 & 8.3 \\
$5+$ & 68 & 51.1 \\
\hline
\end{tabular}

cutaneous leishmaniasis infection and two individuals reported having had tuberculosis. The average age of entry into the mining occupation was 22.4 years. The occupation prior to mining for $40 \%$ was agriculture (Table $3)$. With respect to mercury use, the population fell into two groups: reporting either frequent use or none at all.
Table 3 - Distributions of factors related to mercury exposure among gold miners from Pará, Brasil.

\begin{tabular}{lrr} 
Self-report & $\mathrm{N}$ & $\%$ \\
\hline $\begin{array}{l}\text { Frequency of mercury use } \\
\text { frequently }\end{array}$ & 74 & 59.2 \\
$\quad$ rarely & 7 & 5.6 \\
$\quad$ never & 44 & 32.6 \\
Use mercury for & 65 & 86.7 \\
$\quad$ amalgamation & 10 & 13.3 \\
$\quad$ other & & \\
Use of personal protective equipment & 77 & 91.7 \\
$\quad$ nothing & 6 & 7.1 \\
$\quad$ mask & 1 & 1.2 \\
$\quad$ boots & 22.4 & 7.9 \\
Age begain mining, mean (SD) & & \\
Occupation before mining & 54 & 58.8 \\
$\quad$ agriculture & 77 & 41.2 \\
$\quad$ other & & \\
Laboratory tests, mean (SD) & & \\
$\quad$ blood mercury (ug/dl) & 25.6 & 16.3 \\
$\quad$ urinary mercury (ug/dl) & 21.5 & 20.5 \\
\hline
\end{tabular}

Amalgamation was the most common use of mercury, while $13 \%$ reported using mercury for other purposes. The mean levels of mercury in the blood and urine were $25.6 \mathrm{ug} / \mathrm{dl}$ and $21.5 \mathrm{ug} / \mathrm{dl}$, respectively (Table 3 ). Frequency distributions for each mercury biomarker are shown in Figure 1. The majority of these values were well in excess of the World Health Organization exposure limit guidance ${ }^{35}$ for both blood (74\% above) and urinary (52\% above) levels of mercury. No one reported using appropriate personal protective equipment when handling mercury and no equipment was observed at the site (Table 3).

On examination (Table 4), 4 (3\%) of the participants were febrile with temperature greater than $37.7^{\circ} \mathrm{C}$. Four individuals were considered to be icteric by the examiners; 12 had edema, and 20 had skin ulcers which were not typical of cutaneous leishmaniasis. Eight individuals were hypertensive (blood pressures of systolic $>140 \mathrm{mmHg}$ or diastolic $>90 \mathrm{~mm} \mathrm{Hg}$ ). Giemsastained blood films were read for 133 subjects; 26 (19\%) were positive: 14 for Plasmodium vivax, 11 for $P$. falciparum, and 1 for P. malariae (Table 4). This distribution of plasmodia is similar to that reported by $\mathrm{PAHO}^{25}$.

Many individuals reported experiencing some symptoms (e.g., fatigue, headache, arthralgia, anorexia, memory loss, and insomnia) which might be related to 

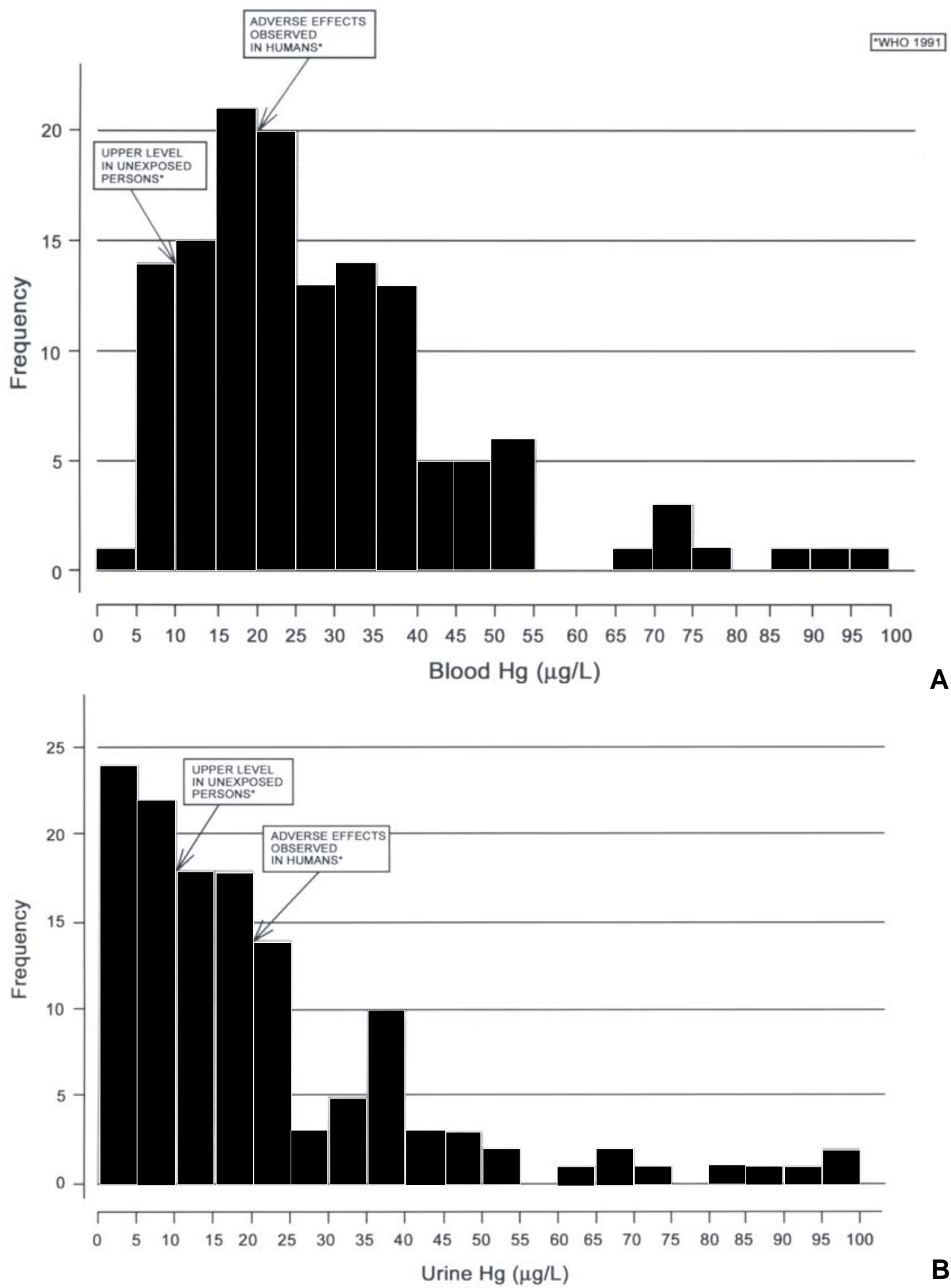

Figure 1 - Histogram of blood (a) and urinary (b) mercury levels among 135 persons associated with a Brazilian gold mine. 
Table 4 - Selected clinical and laboratory findings among gold miners from Pará, Brasil.

\begin{tabular}{lrr}
\hline & $\mathrm{N}$ & $\%$ \\
\hline Clinical exam & & \\
$\quad$ febrile (temp $\left.\geq 37.7^{\circ} \mathrm{C}\right)$ & 4 & 3.2 \\
icteric, & 4 & 3.2 \\
$\quad$ edema & 20 & 10.4 \\
$\quad$ skin ulcers & & 15.9 \\
Abnormal findings & 25 & \\
$\quad$ liver & 35 & 15.9 \\
$\quad$ spleen & 3 & 27.6 \\
$\quad$ lung & 2 & 2.4 \\
$\quad$ eye & 4 & 1.6 \\
$\quad$ abdomen & & 3.2 \\
Laboratory tests & 26 & \\
$\quad$ positive for malaria & & 19.4 \\
type of malaria & 1 & 3.8 \\
malariae & 14 & 53.9 \\
$\quad$ vivax & 11 & 42.3 \\
$\quad$ falciparum & & \\
\hline
\end{tabular}

mercury exposure (Table 5). However, when comparisons were made in groups stratified by blood and urinary mercury levels, the results showed that no relationships between these symptoms and mercury exposure.

Levels of mercury in the blood and urine were not predictive of prevalent malaria infection (Table 6). Selfreported exposure to mercury was also not predictive of current malaria infection. Duration of employment at the garimpo and history of mining were both significantly, but inversely, associated with the relative odds of current malaria infection. Individuals who had been working at the garimpo for less than one year or had been employed in mining for less than 10 years were significantly more likely to be infected with malaria at the time of the examination (OR 3.1 , 95\% Cl 1.0-9.0; OR 2.8, 95\% CI $1.0-8.0$, respectively). Gender was not associated with malaria prevalence. However, compared to individuals with no or only one prior episode of malaria, those with more prior episodes were more likely to be infected with the parasite (Figure 2).

Table 5 - Current clinical symptoms related to mercury exposure by blood and urinary mercury quartile among a gold mining population from Pará, Brasil.

\begin{tabular}{|c|c|c|c|c|c|c|c|c|c|c|c|}
\hline & \multirow[b]{2}{*}{ Total } & \multicolumn{5}{|c|}{ Blood mercury } & \multicolumn{5}{|c|}{ Urinary mercury } \\
\hline & & Quartile 1 & Quartile 2 & Quartile 3 & Quartile 4 & $\mathrm{p}$ (chi square) & Quartile 1 & Quartile 2 & Quartile 3 & Quartile 4 & $p$ (chi square) \\
\hline Skin ulcers & $20(14.8)$ & $4(11.8)$ & $7(20.6)$ & $4(11.8)$ & $5(15.2)$ & 0,72 & $6(17.7)$ & $6(17.7)$ & $4(11.8)$ & $4(12.1)$ & 0,83 \\
\hline Anorexia & $37(27.4)$ & $8(23.5)$ & $7(20.6)$ & $13(38.2)$ & $9(27.3)$ & 0,39 & $9(26.5)$ & $8(23.5)$ & $9(26.5)$ & $11(33.3)$ & 0,84 \\
\hline Fatigue & 63 46.7) & $15(44.1)$ & $12(35.3)$ & $21(61.8)$ & $15(45.5)$ & 0,17 & $13(38.2)$ & $14(41.2)$ & $14(41.2)$ & $22(66.7)$ & 0,07 \\
\hline Headache & $48(35.6)$ & $17(50.0)$ & $9(26.5)$ & $11(32.4)$ & $11(33.3)$ & 0,21 & $14(41.2)$ & $11(32.4)$ & $12(35.3)$ & $11(33.3)$ & 0,88 \\
\hline Myalgia & $23(17.0)$ & $7(20.6)$ & $9(26.5)$ & $2(5.9)$ & $5(15.2)$ & 0,11 & $10(29.4)$ & $3(8.8)$ & $4(11.8)$ & $6(18.2)$ & 0,12 \\
\hline Arthralgia & $41(30.4)$ & $11(32.4)$ & $11(32.4)$ & $11(32.4)$ & $8(24.2)$ & 0,85 & $9(26.5)$ & $12(35.3)$ & $13(38.2)$ & $7(21.2)$ & 0,39 \\
\hline \multicolumn{12}{|l|}{ Vision } \\
\hline problems & $28(20.7)$ & $9(26.5)$ & $5(14.7)$ & $6(17.7)$ & $8(24.2)$ & 0,59 & $7(20.6)$ & $9(26.5)$ & $7(20.6)$ & $5(15.2)$ & 0,73 \\
\hline Insomnia & $31(23.0)$ & $9(26.5)$ & $6(17.7)$ & $12(35.3)$ & $4(12.1)$ & 0,11 & $9(26.5)$ & $6(17.7)$ & $6(17.7)$ & $10(30.3)$ & 0,51 \\
\hline Memory loss & $33(24.4)$ & $13(38.2)$ & $6(17.7)$ & $6(17.7)$ & $8(24.2)$ & 0,17 & $8(23.5)$ & $9(26.5)$ & $6(17.7)$ & $10(30.3)$ & 0,66 \\
\hline Tremors & 25 (18.5) & $6(17.7)$ & $4(11.8)$ & $10(29.4)$ & 5 (15.2) & 0,29 & $8(23.5)$ & $11(32.4)$ & $4(11.8)$ & $2(6.1)$ & 0,02 \\
\hline
\end{tabular}

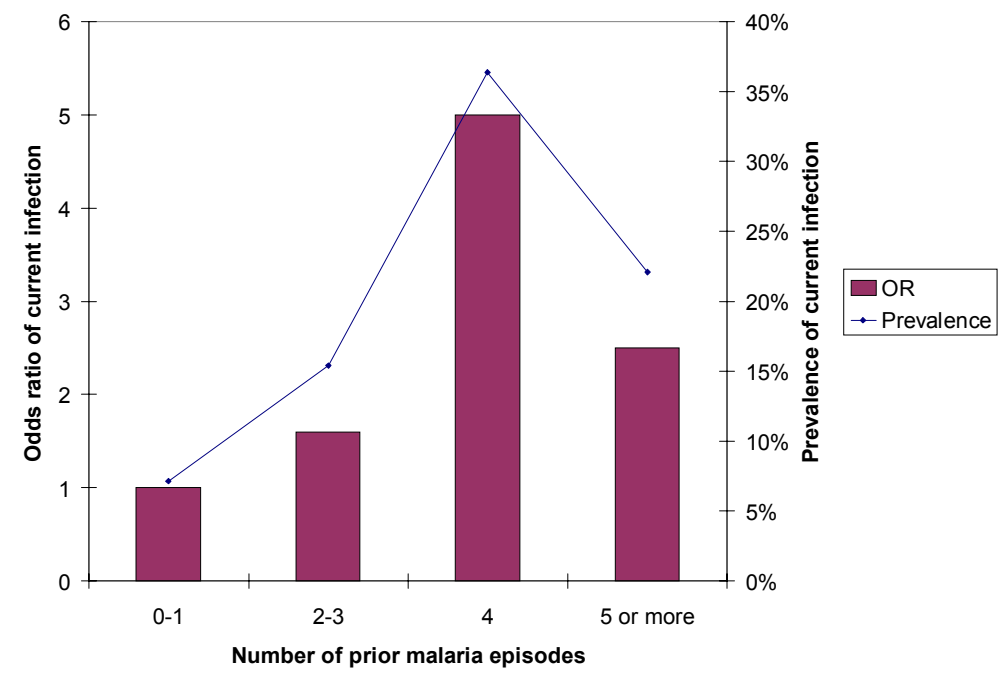

Figure 2 - Prevalence and odds ratio of current malaria infection by number of prior malaria episodes. 
Table 6 - Odds ratio and 95\% confidence interval for current malaria infection among persons associated with a gold mine in Pará, Brasil.

\begin{tabular}{lr}
\hline & OR $(95 \% \mathrm{Cl})$ \\
\hline Quartile of blood mercury & $0.51(0.16-1.6)$ \\
2 vs. 1 & $0.43(0.13-1.4)$ \\
4 vs. 1 & $0.43(0.13-1.4)$ \\
4 vs. 1 & \\
Quartile of urinary mercury & $1.21(0.36-4.1)$ \\
2 vs. 1 & $1.04(0.30-3.6)$ \\
3 vs. 1 & $1.26(0.37-4.2)$ \\
4 vs. 1 & $1.01(0.4-2.6)$ \\
Frequent mercury exposure vs. rare or never & $3.07(1.0-9.0)^{*}$ \\
Duration of employment $<1$ yr at this garimpo vs. $\geq 1$ yr. & $2.82(0.99-8.0)^{*}$ \\
Duration of employment in mining <10 years vs. $\leq 10$ years & \\
Malaria history & $1.58(0.32-7.8)$ \\
$2-3$ prior episodes vs. $0-1$ & $4.95(0.89-27.5)$ \\
$2-4$ prior episodes vs. $0-1$ & $2.45(0.65-9.2)$ \\
$5+$ prior episodes vs. $0-1$ & $1.29(0.49-3.4)$ \\
Sex (male vs. female) &
\end{tabular}

Three of 26 parisitemic individuals were febrile at examination and those with parasitemia were more likely to report a febrile episode within 3 weeks of the exam (30.8\% vs. $17.6 \%)$. Parasitemic individuals were more likely to have symptoms compatible with malaria infection, but the difference was only statistically significant for chills $(p=0.03)$ (Table 7).

Table 7 - Table of malaria-related symptoms by parasitemia status.

\begin{tabular}{lccc}
\hline & $\begin{array}{c}\text { No parasitemia } \\
(\mathrm{n}=109)\end{array}$ & $\begin{array}{c}\text { Parasitemia } \\
(\mathrm{n}=26)\end{array}$ & $\mathrm{p}$ \\
\hline $\begin{array}{l}\text { Temperature (C), mean } \\
\text { Self-report (\%) }\end{array}$ & 36.2 & 36.8 & 0,0007 \\
Fever & & & \\
Fatigue & 17.6 & 30.8 & 0,1483 \\
Chills & 46.3 & 50.0 & 0,8615 \\
& 12.0 & 30.8 & 0,0276 \\
\hline
\end{tabular}

\section{DISCUSSION}

This investigation of small scale gold mining in Brazil found high levels of mercury exposure. Although symptoms compatible with mercury toxicity were prevalent, these were nonspecific in nature and there was no statistical correlation was observed between levels of mercury exposure and reported or observed symptoms. These data are consistent with reports by others on occupational exposures to mercury in artisanal gold mining in Amazônia. Branches et al $(1993)^{5}$ reported somewhat lower exposures among goldmines in Pará in 1993; a similar range of nonspecific symptoms were also reported in these subjects, as well as signs of neurological dysfunction by clinical examination. We are unaware of any cases of clinical mercury poisoning having been reported in the published literature in gold miners in Pará to date. The levels found in most of the subjects in our study are well above health guidelines from $\mathrm{WHO}^{35}$. Compared to levels of mercury in blood for North American populations without occupational exposure, all persons had 10-100 fold elevations in blood mercury ${ }^{23}$. These garimpeiros also had significantly higher levels of urine and blood mercury as compared to most of the Amazonian populations exposed only to mercury via fish consumption (methyl mercury) ${ }^{20} 21$. These data confirm that occupational exposures in artisanal gold mining and crude refining are of the greatest immediate health concern ${ }^{5} 6916$

Malaria has re-emerged as a major problem in South America during the last decade. During 1988, in Loreto, Peru, part of the greater Amazon region, there were no reported cases of malaria. In 1991, there were 140 cases, followed by an explosive annual increase in the number of cases, such that in 1997 there were 121,268 reported cases, including 54,290 slide confirmed cases of $P$. falciparum ${ }^{14}$. In Brazil, the overwhelming majority of reported malaria cases occur in the gold mining areas of the Amazon region. Gold mining contributes to rates and spread of malaria through the ecologic changes associated with mining 
operations for several reasons: 1) gold mining activities bring persons who are immunologically naive to malaria into direct contact with the mosquito vector and the infectious agent; 2) mining methods create ecological niches for mosquitoes to breed, propagate, and survive in pools of water; 3 ) mining operations ensure many repeated contacts between the human reservoirs and the mosquito vector; 4) mining settlements in remote areas are often inaccessible to periodic health surveillance, diagnosis and treatment; and 5) the sociological context of gold mining involves continual out-migration of infected persons, creating a mobile reservoir of human hosts to transfer disease locally and distantly, both in and outside of Brasil ${ }^{26} 29$.

This latter factor may explain the association between gold mining and malaria cases outside the Amazon region. A tracing study by de Souza et al (unpublished) demonstrated that over 1,000 cases occurring as far away as Rio de Janeiro could be linked to contacts with a gold mining site in the Tapajós region of Pará (Figure 3). The episodic nature of gold mining as an occupation ${ }^{8}$ and the movement of persons in and out of gold mining regions in Brazil contribute to this dispersion.

Mercury exposure among the miners may also play a role in malaria transmission in Brazil. Mercury is known to affect the immune system. Mercury induced autoimmunity is associated with nephropathy in rodents and humans ${ }^{1113}$. Recent studies in which mice were exposed to non-lethal doses of malaria showed an attenuated Th1 immune response, ultimately resulting in decreased release of macrophage and splenocyte nitric oxide ${ }^{27} 28$, which is specifically instrumental in a normal immune response to malaria and acquisition of immunity in a murine model ${ }^{31}{ }^{32}$. We have also found that low doses of mercury increase

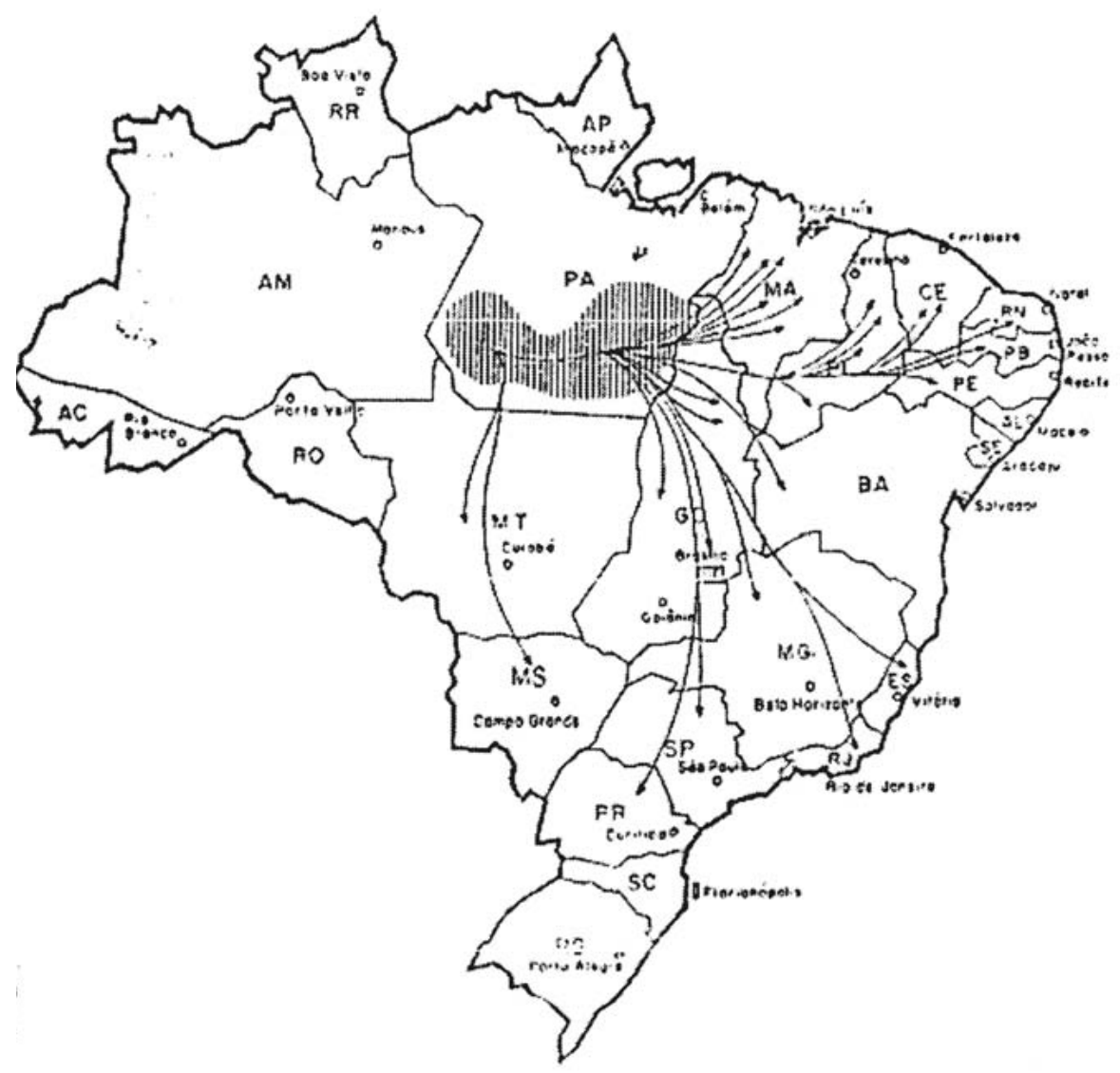

Figure 3 - Trace back diagram of malaria cases occurring in 1992 outside of Amazonia, data from da Souza $J M$. The shaded area in the State of Pará (PA) indicates the region in which all traced cases were found to have contacted plasmodia; this is the region of intensive gold mining of the Tapajós watershed. Abbreviations for states of Brazil: PA - Pará; MT - Mato Grosso; GO - Goiás; MA - Maranhão; CE - Ceará; MS - Mato Grosso do Sul; MG - Minas Gerais; BA - Bahia; RJ - Rio de Janeiro; ES - Espírito Santo; SP - São Paulo; PR - Parana: PI - Piaui; RN - Rio Grande do Norte; PB - Paraiba; PE - Pernambuco; AL - Algoas; $S E-$ Sergipe; $A P$ - Amapá; RR - Roraima; AM - Amazonas; RO-Rondonia; AC - Acre; SC - Santa Catarina; $R S$ - Rio Grande do Sul (Note: Tocantins is not shown). 
host susceptibility to challenges of direct malaria infection and block the acquisition of immunity to $P$. yoeli in the irradiated sporozoite model ${ }^{27}$. Bagenstose et al (2002) recently reported that mercury can also interact with leishmaniasis in an animal model ${ }^{2}$.

We did not find a direct association between mercury exposure and malaria prevalence in our sample, possibly due to the timing of our study, during which a relatively small number of prevalent cases found in this cross sectional study. The current investigation has generated some support for hypotheses regarding a possible effect of mercury on the acquisition of immunity to malaria. Individuals in this garimpo who reported a history of 4 or more prior episodes of malaria infection were more likely to have prevalent malaria infection as compared to those with a self-reported history of 3 or fewer malaria episodes (Figure 2). This pattern is not consistent with experience that suggests that past history of malaria infection reduces the odds of prevalent malaria. For example, in hyperendemic areas, acquisition of immunity to malaria was reported to occur after 3 or more infections with the parasite ${ }^{3}$. Our observations are consistent with the hypothesis that mercury exposure may interfere with the expected natural acquisition of immunity to malaria, as found in our murine model ${ }^{27}$. However, confirmation of this hypothesis will require a prospective study of malaria transmission, infection, and mercury exposure.

The relationship between ecologic/environmental change and infectious disease has received increasing worldwide attention ${ }^{34}$. A memorable example of the effect of development is the building of the Aswan High Dam in Egypt, which was followed by an increase in the distribution of the vector and the size of the exposed population exposed to schistosomiasis ${ }^{30}$. However, virtually no attention has focused on the ecologic and environmental impacts on infectious disease of chemical contamination, which accompanies industrialization and resource exploitation in many developing countries.

Our study was limited in several respects. We only assessed exposures to inorganic mercury, associated with gold mining. Some subjects may have also been exposed to methyl mercury from consuming mercurycontaminated fish. Our measurements of mercury were in blood and urine, rather than hair, and were of total mercury only. We may not have found the garimpeiros most severely affected by mercury in Piranha, since those individuals may not have been able to walk to the site of our field clinic. At the garimpo many of the workers were living at baixãos (or lower areas), up to 8 hours away on foot. The small size of the sample, with only 26 persons having current parasitemia, prevented us from rigorously testing associations in subgroups, such as those who had been at the garimpo for varying periods of time. Self-report data on prior malaria infections may have been unreliable, representing only history of fever (no parasitological confirmation was available at the garimpo), or recurrent febrile episodes of the same primary malaria infection, which could have been inadequately treated. Finally, because of the cross-sectional design, we could not directly test the hypothesis that mercury exposures subsequently alter human resistance to malaria.

Our investigation documents and underscores the concern that widespread use and significant exposures to mercury occur in Brazilian garimpos, despite policies prohibiting its use in gold amalgamation. Previous studies have reported similar findings on smaller groups ${ }^{579}$. There is an urgent need to control exposures to mercury among the garimpeiros, in order to prevent mercury intoxications, regardless of any interactions with malaria susceptibility. Since mercury use is already illegal in Brazil, policy recommendations alone are not effective. If mercury exposure turns out to be linked to a proportion of Brazil's malaria problem, a paradigm shift in the policy debate on mercury use may gain some momentum. Thus, while our investigation was not able to test the mercury-immunity hypothesis directly, we believe there is sufficient evidence and need to pursue further field investigations with regard to mercury exposure and acquisition of immunity to malaria in Brazil and other countries with artisanal use of mercury in mining. The prevention and treatment approaches currently applied to the garimpos are inadequate and must be increased.

\section{ACKNOWLEDGEMENTS}

We wish to acknowledge the important contributions of Olaf Malm, Donna Mergler, David Cleary, and the members of the Association of Mine Workers and Mine Owners of the Tapajos (AMOT) in the conduct and analyses of this study. Also, the participation of many colleagues at the Instituto Evandro Chagas (FUNASA), especially Dra E.C.O. Santos, was critical to the success of this project.

\section{REFERENCES}

1. Ault SK. Effect of demographic patterns, social structure and human behavior on malaria. In: Service MW (ed) Demography and Vector Borne Diseases. Boca Raton, Florida: CRC Press, p. 283-301, 1989

2. Bagenstose LM, Mentink-Kane MM, Brittingham A, Mosser DM, and Monestier M. Mercury enhances susceptibility to murine leishmaniasis. Parisite Immunology 633-640, 2001.
3. Baird JK. Age-dependent characteristics of protection v. susceptibility to Plasmodium falciparum. Annals of Tropical Medicine and Parasitology 92:367-390, 1998.

4. Bouma MJ, Poeda G. Rojas W. Predicting high-risk years for malaria in Colombia using parameters of El Nino Southern Oscillation. Tropical Medicine and International Health 2:1122-1127, 1997. 
5. Branches FJP, Erickson R, Aks SE, Hryhorczuk DO. The price of gold: mercury exposure in the Amazonian rain forest. Journal of Toxicology, Clinical Toxicology 31:295-306, 1993.

6. Camara V, Corey G. O Caso dos Garimpos de Ouro no Brasil. Metepac (Mexico): ECO/Pan-American Health Organization, 1992.

7. Cleary D, Thornton L, Brown N, Kazantzis G, Delves T, Worthington S. Mercury in Brazil. Nature 369:613-614, 1994.

8. Cleary D. Anatomy of the Amazon Gold Rush. Macmillan, London, 1990.

9. Counter SA, Buchanan LH, Laurell G, Ortega F. Blood mercury and auditory neuro-sensory responses in children and adults in the Nambija gold mining area of Ecuador. Neurotoxicology 19:185-196, 1998.

10. Cunha ML, Piovesan-Alves F, Pang LW. Community-based program for malaria case management in the Brazilian Amason. American Journal of Tropical Medicine and Hygiene 65:872-876, 2001.

11. Druet $P$, Bernard A, Hirsch F. Immunologically mediated glomerulonephritis induced by heavy metals. Archives of Toxicology 50:187-194, 1982.

12. Grandjean $P$, White RF, Nielsen A, Cleary D, and de Oliveira Santos EC. Methylmercury neurotoxicity in Amazonian children downstream from mining. Environmental Health Perspectives 107; 587-591, 1991.

13. Griem P, Gleichmann E. Metal ion induced autoimmunity. Current Opinion in Immunology 7:831-838, 1995.

14. Guarda JA, Asayag CR, Witzig R. Malaria reemergence in the Peruvian Amazon region. Emerging Infectious Diseases 5:209-215, 1999.

15. Hacon S, Artaxo P, Campos RC. Atmospheric mercury and trace elements in the region of Alta Floresta in the Amazon basin. Water Air and Soil Pollution: An International Journal of Environmental Pollution 80:273-283, 1995.

16. Harada M, Nakanishi J, Yasoda E, Pinheiro MC, Oikawa T, Assis Guimaraes GA, Cardoso BS, Kizaki T, Ohno H. Mercury pollution in the Tapajos River basin, Amazon: mercury level of head hair and health effects. Environment International 27: 285-290, 2001.

17. Lacerda LD. Global mercury emissions from gold and silver mining. Water Air and Soil Pollution: An International Journal of Environmental pollution 97:209-221, 1997.

18. Lawrence D, McCabe M. Immunotoxicity of metals. In: Goyer RA, Klaassen CD, Waalkes MP (eds ) Metal Toxicology. Academic Press,San Diego, p. 305-338, 1995.

19. Lebel J, Mergler D, Branches F, Lucotte M, Amorim A, Dolbec J, Larribe F. Neurotoxic effects of low-level methylmercury contamination in the Amazonian Basin. Environmental Research 79:20-32, 1998.

20. Lebel J, Roulet M, Mergler D, Lucotte M, Larribe F. Fish diet and mercury exposure in a riparian Amazonian ppulation. Water Air and Soil Pollution: An International Journal of Environmental Pollution 97:31-44, 1997.

21. Lodenius M, Malm O. Mercury in the Amazon, Reviews of Environmental Contamination and Toxicology 157:25-52, 1998.

22. Loevinsohn ME. Climatic warming and increased malaria incidence in Rwanda. Lancet 343:714-718, 1994.

23. Mahaffey KR, Mergler D. Blood levels of total and organic mercury in residents of the upper St Lawrence River Basin, Quebec: Association with Age, gender and fish consumption. Environmetal Research 77:104-114, 1998.

24. Meegan JM, Moussa MI, el-Mour AF, Toppouzzada RH, Wyess RN. Ecological and epidemiological studies of Rift Valley fever in Egypt. Journal of the Egyptian Public Health Association 53:173-175, 1978.

25. Pan-American Health Organization. Malaria in the Americas. Epidemiological Bulletin 17:1-6, 11, 1996.

26. Sawyer D. Malaria on the Amazon frontier: economic and social aspects of transmission and control. Southeast Asian Journal of Tropical Medicine and Public Health 17:342-345, 1986.

27. Silbergeld EK, Sacci J, Azad AF. Mercury exposure and murine response to Plasmodium yoelii infection and immunization. Immunopharmacology and Immunotoxicology 22:685-695, 2000.

28. Silbergeld EK, Woodruff S, Gutirrez P, McKenna K, Azad A, Sacci J. Effects of mercury (HG) on immune function in male and female mice. (Abstr. 1012). Toxicological Sciences 1998.

29. Singer BH, Castro MC. Agricultural Colonization and Malaria on the Amazon Frontier. Annals of the New York Academy of Sciences 954:184-222; 2001.

30. Strickland GT, Abdel Wahab MF. Schistosomiasis in the Aswan High Dam Lake. Egyptian Journal of Bilharziasis 12:197-205, 1990.

31. Taylor-Robinson AW, Phillips RS, Severn A, Moncada S, Liew FY. The role of TH1 and TH2 cells in a rodent malaria infection. Science 260:1931-1934, 1993.

32. Van der Heyde HC, Manning DD, Weidanz WP. Role of CD4+ T cells in the expansion of the CD4-, CD8- gamma delta $T$ cell subset in the spleens of mice during blood-stage malaria. Journal of Immunology 151:6311-6317, 1993.

33. Veiga MM, Meech JA, Onate M. Mercury pollution from deforestation. Nature 168:816-817, 1994.

34. World Health Organization. World Health Report 1996: Fighting Disease, Fostering Development. Geneva WHO, 1996.

35. World Health Organization. Environmental Health Criteria: Mercury. Geneva WHO-IPCS, 1991. 